\title{
Assessment of crop growth, soil properties and crop yield in an upland acidic soil with inorganic fertilizer blended with organic amendments in summer rice cropping seasons
}

\author{
Madhumita Ghosh ${ }^{1} \cdot$ Ashalata Devi $^{1}$ \\ Received: 23 April 2018 / Accepted: 25 February 2019 / Published online: 14 March 2019 \\ (c) The Author(s) 2019
}

\begin{abstract}
Purpose Intensification of rice cultivation to meet the growing demand has imbalanced the nitrogen level in soil. Amendments of inorganic fertilizers increase yield, but at the same time affects the environment. Hence, different amendments are to be investigated which acting sustainably on soil and the environment upholds yield gains.

Methods A study was carried out on acidic sandy loam soil in the irrigated summer seasons of the years of 2015-2016 and 2016-2017 to examine the effects of various amendments on rice growth, soil health and yield. The applied amendments were inorganic fertilizer blended with crop residues, farm yard manure and compost made of daily household green wastes. Results The highest yield of $53.33 \pm 2.09 \mathrm{Q} / \mathrm{ha}$ was recorded with application of inorganic fertilizer blended with compost and the lowest yield of $32.71 \pm 3.09 \mathrm{Q} / \mathrm{ha}$ without amendment. Strong positive correlations were found between soil moisture and volumetric water content $(0.982$ at $p<0.001)$, manganese and copper $(0.900$ at $p<0.001)$, whereas available phosphorus and manganese showed a strong negative correlation $(-0.901$ at $p<0.001)$. Performing stepwise regression analysis, yield was found affected mostly by soil moisture and total carbon out of evaluated 17 soil traits.

Conclusion The inorganic fertilization blended with the compost increased rice yield by $13.61 \%$ over inorganic fertilizer but a higher yield associated with compost demoted total nitrogen contents in soil, leading to lower soil nitrogen fertility and providing a negative feedback to sustainable agriculture. More research is required on compost development and application in different rice agroecosystems.
\end{abstract}

Keywords Inorganic fertilizer · Organic amendments · Soil properties $\cdot$ Rice field

\section{Introduction}

Rice (Oryza sativa Lin.) is the most demanding cereal in the world. It appears as an indispensable food for more than $50 \%$ of the world's population. Its requirement is increasing rapidly for fulfilling the demand of ever growing human population. To meet this rising demand, different approaches are being practised, such as boosting rice production with the application of different fertilizers (Cassman et al. 1998),

Madhumita Ghosh

mghosh@tezu.ernet.in

Ashalata Devi

kh_asha@tezu.ernet.in

1 Department of Environmental Science, Tezpur University, Tezpur 784 028, India cultivating high yielding rice varieties and going forward with instructions issued by governments.

The application of nitrogen fertilizer promotes the rice yield, but it also has unfavourable effects on the environment and soil health (Leip et al. 2014). One of the most common steps taken in the direction of maintaining soil health and environment is the use of organic fertilizers. Such fertilizers provide essential nutrients to soil, and also improve other soil properties, such as water-holding capacity, nutrient-holding capacity and microbial activity of soil. However, a huge volume of organic fertilizer is required for achieving potential of high yielding rice varieties, which will directly step up the cost of farming (Baruah and Baruah 2015; Baruah et al. 2016). In addition, the decomposition of an organic matter under humid tropical condition is relatively hasty and its gathering is minimal in upland irrigated soils. 
Hence, a balanced approach that can be used to sustainably improve rice yield and soil quality is to apply wastes produced from kitchen, garden and farm (crop residues and farm yard manure) in combination with inorganic fertilizers. The application of such a blended amendment will have a greater chance to endure a fairly lofty amount of nutrients required for a high yielding rice variety and also to improve soil traits. Moreover, composting of eco-friendly organic wastes is a good option to provide a high-quality green fertilizer as a supplement to inorganic fertilizer. The use of compost increases organic carbon and moisture retention ability of soil, while decreases its bulk density. Soil organic carbon and total nitrogen act as basic elements of green agriculture (Franzluebbers and Stuedemann 2009). Hence, restoration of soil organic carbon is required for enhancing rice production by maintaining soil quality, and also to raise the soil carbon store to decrease the release of carbon dioxide from soil. On the other hand, the renewal of nitrogen is desirable for lowering the need of nitrogen fertilizers by avoiding the percolation of nitrogen and release of nitrous oxide to the atmosphere.

Motivated by above, a field trial was undertaken with the rice variety of Naveen in the summer cropping season. With the aim of enhancing rice production, the investigation was concentrated on studying the effects of organic wasteblended inorganic fertilizer on rice growth, soil properties and rice yield. Finally, the cloud of data related to plant growth, soil properties and rice yield were analyzed through statistical tools to identify the soil attributes affecting the yielding of rice.

\section{Materials and methods}

\section{Experimental design and field management}

A 2-year field trial in the summer rice cropping system was performed on an experimental site inside the Tezpur University Campus $\left(26^{\circ} 41^{\prime} \mathrm{N}, 92^{\circ} 50^{\prime} \mathrm{E}\right)$ situated in the north bank plain zone of Agroclimatic division of Assam in India. The area is under moist subtropical monsoon climate. The study period was from the last week of February to the third week of June in the years of 2016 and 2017. Before starting the experiment, the physico-chemical properties of the soil were determined using applicable methods.

Two months prior to the starting of the field trial, the compost was prepared using eco-friendly organic waste materials. For this, a mixture was prepared first with kitchen wastes (peels of vegetables and fruits, rotten vegetables, leftover cooked food, used tea leaves, etc.), garden wastes (grasses and bushes) and farm waste (cow dung manure) in the ratio of 1:2:2. Then, the compost was formed by concealing the mixture for 2 months in a ditch under ambient air temperature.

In the field experiment, 6 treatments were replicated 4 times in a random block design (RBD), for which a total of 24 plots were prepared in 4 parallel blocks. Each plot was $2 \mathrm{~m} \times 2 \mathrm{~m}$ in size. A gap of $50 \mathrm{~cm}$ wide was left between two adjacent plots for preventing intermixing of amendments. The six treatments were marked by $\mathrm{T} 1$ through T6 as follows: $\mathrm{T} 1=\mathrm{No}$ amendment, $\mathrm{T} 2=\mathrm{NPK}$ (inorganic fertilizer), $\mathrm{T} 3=\mathrm{NPK}+$ crop residue of $5 \mathrm{t} / \mathrm{ha}$ (ton per hectare), T4 $=\mathrm{NPK}+$ farm yard manure $(\mathrm{FYM})$ of $5 \mathrm{t} / \mathrm{ha}$, $\mathrm{T} 5=\mathrm{NPK}+\mathrm{FYM}$ of $10 \mathrm{t} / \mathrm{ha}$, and T6 $=\mathrm{NPK}+$ compost of $2.5 \mathrm{t} / \mathrm{ha}$. Although the package of practices published by the Government of Assam recommends to apply 10 t/ha FYM during field preparation (Anonymous 2015), treatment T4 was considered to assess the impact of its half (i.e., $5 \mathrm{t} / \mathrm{ha}$ ). Along with the amendments as per the field layout, urea, single superphosphate (SSP) and muriate of potash (MOP) were applied in the ratio of 60:30:30 as the NPK (inorganic fertilizer). Fifty percent (50\%) of the portion of urea was added with the whole portions of SSP and MOP as the basal fertilizer, $25 \%$ was applied in the middle of the tillering stage and the remaining $25 \%$ was applied in the panicle initiation stage of active vegetative growth of rice. The moisture contents in the organic materials (crop residue, FYM and compost) and the corresponding C:N ratios at the time of the application of the amendments were assessed as $(12.70 \%$, 48.97), (46.94\%, 14.41) and $(35.49 \%, 10.58)$, respectively.

Approved seedlings of 35 days old of Naveen rice variety were gathered from the Regional Agriculture Research Station, Nagaon, and they were transplanted manually in row to row of $20 \mathrm{~cm} \times 20 \mathrm{~cm}$ and plant to plant spacing of $20 \mathrm{~cm}$ with two seedlings per hill. The field was irrigated twice a week as per a scheme of intermittent irrigation. The plots were irrigated in a way to hold $5 \mathrm{~cm}$ of standing water until panicles initiated. Manual weeding, application of insecticides and pesticides were also done regularly as per the suggestion set out by the Government of Assam.

\section{Plant sampling and analysis}

Plant height is obtained from the plants of three hills selected from three random plots per amendment, excluding the boarder hills of the plots. The plant height was measured from the stem base of a plant to the tip of its longest leaf or panicle, whichever was longer.

In the case of biomass, a destructive sampling of three plants per amendment was collected and removed the stuck soil by washing with water. Separating the roots, shoots and leaves of the plants, they were dried in an oven at $75 \pm 2{ }^{\circ} \mathrm{C}$ temperature until their constant weights were obtained. Those dried weights were their respective biomass 
values, i.e., root biomass, shoot biomass and leaf biomass, respectively.

\section{Soil sampling and analysis}

For determining the properties of the initial soil, a composite soil sample was prepared by mixing soil samples collected from four different sites of the experimental field. For the properties of the soil after the experiment, another composite soil sample was prepared by collecting soil samples after harvest from three plots per amendment. In both cases, soil samples were obtained from a depth of $0-15 \mathrm{~cm}$ using an iron probe of $2 \mathrm{~cm}$ diameter.

Soil moisture (SM) content was measured from a portion of each composite sample using the gravimetric method. For obtaining other soil properties, the remaining portion of the composite sample was first dried in open air, then grounded, and finally passed through a sieve having pores $2 \mathrm{~mm}$ in size. The concentration of soil organic carbon (SOC) was evaluated through the potassium dichromate oxidation process conceived by Walkly and Black (1934). Total nitrogen (TN) and total carbon (TC) in soil were estimated by a carbon hydrogen nitrogen (CHN) analyser (model: 2400 series 2, USA). The soil catalase activity (CAT) was determined using the method provided by Zhang et al. (2012). The available nitrogen, available phosphorus and available potassium in the soil were evaluated using the method proposed by Page et al. (1982). The iron, copper, manganese and zinc were first extracted by diethylene-triamine-pentaacetic acid (DTPA) and then quantified through a mass spectrophotometer (Model: Perkin Elmer Optima 2100DV).

For obtaining the soil bulk density (BD), three soil cores, each of $15 \mathrm{~cm}$ in length and $5 \mathrm{~cm}$ in diameter, were taken from plots under each treatment, and dried at $105^{\circ} \mathrm{C}$ temperature. Then, $\mathrm{BD}$ for each core was calculated by dividing the difference in its initial and dried weights by the core volume. Then, the average of the BD values of the three cores under a treatment is taken as the ultimate BD under the treatment.

Finally, the volumetric water content (VWC) and waterfilled pore space were calculated from the obtained SM and $\mathrm{BD}$ values using the formula proposed by Brzezinska et al. (2005).

\section{Yield and yield-related parameters}

From three random plots under each treatment, an area of $1 \mathrm{~m} \times 1 \mathrm{~m}$ was chosen from each plot for determining productive tillers and sterility percentage. The matured grains containing $14 \%$ moisture were harvested from the areas, and then the harvest index was calculated using the formula as given by Liu et al. (2013). Further, the panicle length, filled grain and weight of thousand grains were also determined.
In addition, using the average yield of 2 years of experimentation, the partial factor productivity and nitrogen agronomic efficiency were calculated through the formulae given by Guo et al. (2017) and yield contribution of nitrogen was calculated through the formula given by Tian et al. (2017).

\section{Statistical analysis}

In the statistical software package SPSS (version 15), oneway ANOVA was conducted to investigate if any significant difference exists among the calculated mean values of the crop growth, soil property and yield-related parameters under different amendments. The Tukey's HSD test was also performed for identifying the mean values under amendments $\mathrm{T} 2$ through $\mathrm{T} 6$, which are significantly different from the corresponding mean values under amendment T1. Further, the PCA (principal component analysis) tool of SPSS was used to identify the correlated soil properties and to isolate the disparate ones. Next, the stepwise linear regression was performed for relating rice yield with the applicable soil properties, i.e., to investigate how soil properties influence rice yielding.

\section{Results and discussion}

The soil texture of the experimental site was sandy and slightly acidic having $\mathrm{pH}$ value of 5.6. The $\mathrm{SM}$ and $\mathrm{BD}$ values were found to be $36.7 \%$ and $1.31 \mathrm{~g} / \mathrm{cm}^{3}$, respectively. The physico-chemical properties of the soil in detail are presented in Table 1.

\section{Crop growth}

For the data pooled from the summer cropping seasons of the years of 2016 and 2017, the variations in the plant morphological attributes under different treatments are shown in Table 2, where it is observed that the amendments brought noticeable changes in the growth of the rice plants.

The plant height during the crop growth period increased almost equally under all the amendments, recoding the maximum of $(106.40 \pm 0.30) \mathrm{cm}$ under $\mathrm{T} 2$ and the minimum of $(80.36 \pm 0.31) \mathrm{cm}$ under $\mathrm{T} 1$ at the final stage (i.e., at harvest). Treatment T2 contained only NPK, which released nutrients speedily causing the plants to grow faster.

Unlike plant height, the number of tillers per hill showed a growing trend from the tillering stage to the flowering stage and then decreased at the harvest, showing the highest value of $18 \pm 0.57$ under T6 and the lowest value of $9 \pm 0.57$ under T1. The result was similar to that of Yung-Yu (2005), where a rice pot experiment was performed with two different composts. 
Table 1 Soil physico-chemical properties (mean \pm standard deviation) of the experimental site (at $0-15 \mathrm{~cm}$ depth) before starting the experiment

\begin{tabular}{lc}
\hline Property & Value \\
\hline Sand (\%) & $60.5 \pm 0.61$ \\
Slit (\%) & $20.2 \pm 0.82$ \\
Clay (\%) & $19.3 \pm 0.96$ \\
Moisture (\%) & $36.7 \pm 2.64$ \\
Bulk density $\left(\mathrm{Mg} / \mathrm{m}^{3}\right)$ & $1.31 \pm 0.10$ \\
Porosity $(\%)$ & $50.60 \pm 1$ \\
Volumetric water content $(\%)$ & $48.04 \pm 1$ \\
Water-filled pore space (\%) & $94.94 \pm 1$ \\
pH & $5.6 \pm 0.67$ \\
Organic carbon $(\%)$ & $1.59 \pm 0.71$ \\
Total carbon $(\mathrm{g} / \mathrm{kg})$ & $20.7 \pm 2.07$ \\
Total nitrogen $(\mathrm{g} / \mathrm{kg})$ & $6.0 \pm 0.01$ \\
Available nitrogen $(\mathrm{kg} / \mathrm{ha})$ & $212.0 \pm 6.99$ \\
Available phosphorus $(\mathrm{kg} / \mathrm{ha})$ & $12.15 \pm 4.52$ \\
Available potassium $(\mathrm{kg} / \mathrm{ha})$ & $70.65 \pm 8.90$ \\
Micronutrients & \\
Iron (mg/kg) & $23.1 \pm 2.01$ \\
Copper (mg/kg) & $1.75 \pm 0.1$ \\
Zinc (mg/kg) & $0.74 \pm 0.01$ \\
Manganese (mg/kg) & $3.40 \pm 0.1$ \\
\hline
\end{tabular}

The number of leaves per hill showed a similar trend like the number of tillers per hill, increased from the tillering stage to the flowering and then decreased at the harvest. The maximum of $40 \pm 0.33$ number of leaves were found under $\mathrm{T} 5$ and the minimum of $24 \pm 0.33$ under T1 at the harvest.

Increasing trend in root length was noticed under T2-T4 and $\mathrm{T} 6$ in the period in between the tillering and flowering stages, and under T1, T3 and T5 at the harvest; while a decreasing trend under T2, T4 and T6 at the harvest. Such trends of variation in the root length indicate that the soil faced alternate wetting and drying.

Due the above-stated trends in the growth of the plants, there were significant differences in both above and below ground biomass under different amendments in comparison to those under T1 during the investigation of all the three cropping stages (tillering, flowering and harvest stages). Both above and below ground biomass showed uprising trends from the tillering stage to the flowering stage under all the six treatments; while decreasing trends at the harvest were shown by the above ground biomass under T2 and T4, and by the below ground biomass under T1-T3. Both above and below ground biomass attained their maximum values under T5 and minimum values under T1.

Table 2 Variation in plant morphological attributes (mean \pm standard error) under different treatments in a 2-year field experiment in the summer cropping seasons (Tukey's HSD test at significance level of 5\%)

\begin{tabular}{|c|c|c|c|c|c|c|c|}
\hline Treatment & Growth stage & Height (cm/hill) & Tiller number/hill & Leaf number/hill & Root length (cm/hill) & $\begin{array}{l}\text { Above ground } \\
\text { biomass (g/hill) }\end{array}$ & $\begin{array}{l}\text { Below ground } \\
\text { biomass (g/hill) }\end{array}$ \\
\hline $\mathrm{T} 1$ & Tillering & $30.10 \pm 0.05$ & $8 \pm 0.57$ & $19 \pm 1.20$ & $5.4 \pm 0.12$ & $0.68 \pm 0.01$ & $0.19 \pm 0.01$ \\
\hline $\mathrm{T} 2$ & & $41.5 \pm 0.28 *$ & $12 \pm 0.57$ & $28 \pm 1.85^{*}$ & $5.03 \pm 0.88$ & $1.41 \pm 0.02 *$ & $0.26 \pm 0.01 *$ \\
\hline $\mathrm{T} 3$ & & $42.10 \pm 0.05^{*}$ & $18 \pm 0.88^{*}$ & $37 \pm 0.88^{*}$ & $4.96 \pm 1.20$ & $1.79 \pm 0.01 *$ & $0.35 \pm 0.01 *$ \\
\hline $\mathrm{T} 4$ & & $39.10 \pm 0.05^{*}$ & $13 \pm 0.33^{*}$ & $35 \pm 0.33^{*}$ & $4.30 \pm 0.05^{*}$ & $1.85 \pm 0.01 *$ & $0.44 \pm 0.01$ \\
\hline T5 & & $60.26 \pm 0.12 *$ & $14 \pm 1.20^{*}$ & $42 \pm 0.88^{*}$ & $8.16 \pm 0.88^{*}$ & $2.50 \pm 0.01 *$ & $0.65 \pm 0.01 *$ \\
\hline T6 & & $39.36 \pm 0.27 *$ & $12 \pm 0.88^{*}$ & $33 \pm 1.80^{*}$ & $7.16 \pm 0.88^{*}$ & $1.85 \pm 0.01 *$ & $0.47 \pm 0.00^{*}$ \\
\hline $\mathrm{T} 1$ & Flowering & $74.10 \pm 0.49$ & $11 \pm 0.57$ & $47 \pm 0.57$ & $5.3 \pm 0.08$ & $14.35 \pm 0.01$ & $2.14 \pm 0.00$ \\
\hline $\mathrm{T} 2$ & & $79.23 \pm 0.38^{*}$ & $16 \pm 0.33^{*}$ & $51 \pm 0.57 *$ & $10.16 \pm 0.16^{*}$ & $43.76 \pm 0.01 *$ & $3.20 \pm 0.01 *$ \\
\hline $\mathrm{T} 3$ & & $92.50 \pm 0.05^{*}$ & $14 \pm 0.00^{*}$ & $64 \pm 0.33^{*}$ & $8.10 \pm 0.10^{*}$ & $35.92 \pm 0.04 *$ & $3.21 \pm 0.01 *$ \\
\hline $\mathrm{T} 4$ & & $87.00 \pm 0.57 *$ & $18 \pm 0.33^{*}$ & $67 \pm 0.33^{*}$ & $11.23 \pm 0.25^{*}$ & $39.12 \pm 0.28 *$ & $3.94 \pm 0.01 *$ \\
\hline T5 & & $94.00 \pm 0.57 *$ & $17 \pm 0.66^{*}$ & $63 \pm 0.33^{*}$ & $5.10 \pm 0.10$ & $24.11 \pm 0.01 *$ & $2.54 \pm 0.01 *$ \\
\hline $\mathrm{T} 6$ & & $92.00 \pm 0.57 *$ & $20 \pm 0.33^{*}$ & $68 \pm 0.33^{*}$ & $11.46 \pm 0.05^{*}$ & $35.90 \pm 0.01 *$ & $4.49 \pm 0.01^{*}$ \\
\hline $\mathrm{T} 1$ & Harvest & $80.36 \pm 0.31$ & $9 \pm 0.57$ & $24 \pm 0.33$ & $8 \pm 0.25$ & $24.62 \pm 0.21$ & $1.87 \pm 0.01$ \\
\hline $\mathrm{T} 2$ & & $106.40 \pm 0.30 *$ & $11 \pm 0.33$ & $34 \pm 0.57 *$ & $10 \pm 0.26^{*}$ & $39.64 \pm 0.74 *$ & $3.05 \pm 0.02 *$ \\
\hline T3 & & $93.43 \pm 0.64 *$ & $17 \pm 0.57 *$ & $36 \pm 0.33^{*}$ & $9 \pm 0.05^{*}$ & $44.90 \pm 0.34 *$ & $4.39 \pm 0.10^{*}$ \\
\hline $\mathrm{T} 4$ & & $98.43 \pm 0.31 *$ & $15 \pm 0.57 *$ & $20 \pm 0.33^{*}$ & $8 \pm 0.05$ & $34.16 \pm 0.41 *$ & $2.67 \pm 0.00^{*}$ \\
\hline $\mathrm{T} 5$ & & $107.83 \pm 0.44 *$ & $14 \pm 0.88^{*}$ & $40 \pm 0.33^{*}$ & $11 \pm 0.11^{*}$ & $55.55 \pm 0.17 *$ & $3.15 \pm 0.01 *$ \\
\hline T6 & & $104.50 \pm 0.28 *$ & $18 \pm 0.57^{*}$ & $36 \pm 0.33^{*}$ & $6 \pm 0.10^{*}$ & $56.71 \pm 0.24 *$ & $6.82 \pm 0.06^{*}$ \\
\hline
\end{tabular}

Values with * in the same column are significantly different from the corresponding value under T1 of each growth stage. T1: No amendment, T2: NPK, T3: NPK + crop residue (5 t/ha), T4: NPK + farm yard manure (5 t/ha), T5: NPK + farm yard manure (10 t/ha), T6: NPK+ compost $(2.5 \mathrm{t} / \mathrm{ha})$ 


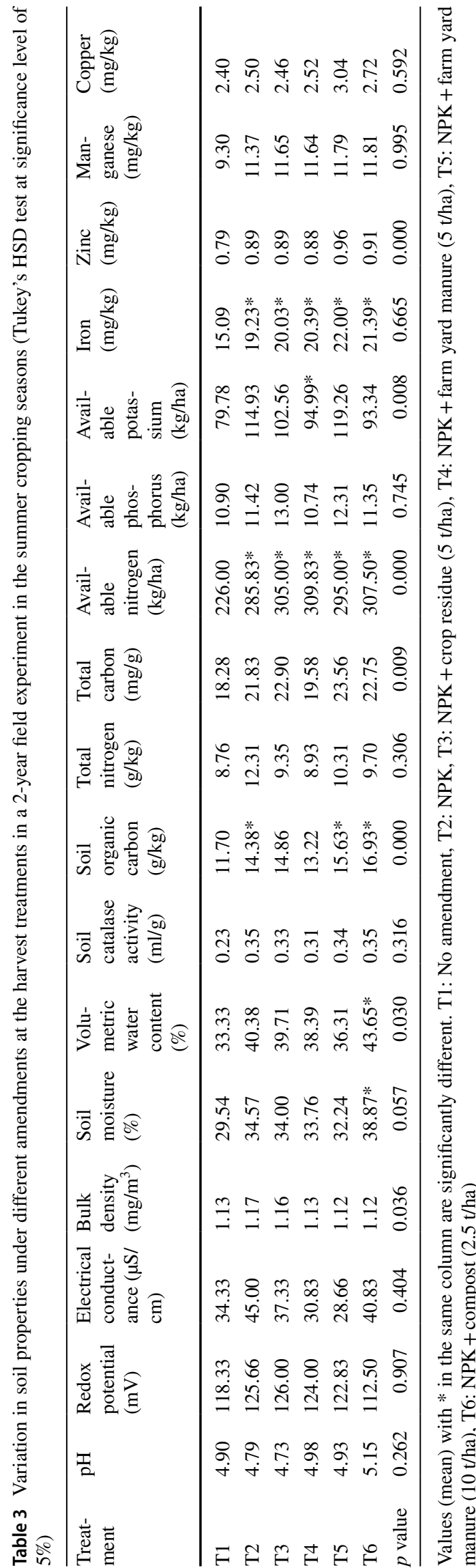

\section{Soil properties}

The variations in soil properties at the harvest under different amendments are shown in Table 3, where it is observed that the soil under T6 (compost-blended amendment) had the best/highest values of soil moisture (SM), volumetric water content (VWC), soil catalase activity (CAT), soil organic carbon (SOC), and iron and manganese; while their lowest values occurred in the soil under T1. Also, the best/highest value of $\mathrm{pH}$ was found under $\mathrm{T} 6$ and its lowest under T3. The soil bulk density was the best/lowest under T6 (also under T5), and the highest under T2. Moreover, the maximum and minimum values of available phosphorus were found under T3 and T4, respectively. Further, $\mathrm{T} 1$ showed the lowest values of total nitrogen (TN), total carbon (TC), available nitrogen $(\mathrm{N})$, available phosphorus $(\mathrm{P})$, available potassium (K), zinc and copper also, with their better/highest values occurring under other amendments out of T2-T5. It is to be mentioned that different organic materials, used as composting materials, release different nutrients, e.g., Laos et al. (2000) and Kowalijiow and Mazzarino (2007) found higher release of phosphorus by the compost prepared with fish bio-solid as one of the constituents, and Watanabe et al. (2018) found higher release of total carbon by the compost prepared with straw as one of the constituents.

The best SM and VWC under the compost-blended T6 directly supported the work of Zemanek (2011). The presence of higher SM and VWC in compost enhances the microbial activity, which helps in the growth of crops by releasing easily absorbable nutrients.

The finding of the best bulk density under T6 (also under T5) and the worst under $\mathrm{T} 2$ was in the line of the work of (Gudadhe et al. 2015), who reported that the effect of organic blended inorganic fertilizer on bulk density is more pronounced than that of inorganic fertilizer alone. Further, Santhy et al. (1999) also found that the application of organic manure in a blended experiment reduces the bulk density. The fact is that the organic carbon contained in organic materials reduces bulk density when such materials are used as a fertilizer.

As the addition of organic materials to soil channels the accumulation of extra carbon (Bharali et al. 2017; Baruah and Baruah 2015; Kirkby et al. 2013), SOC was found enhanced under T3, T5 and T6, i.e., under the inorganic fertilizer blended with organic materials. The increased SOC helps microbes to provide nutrients to plants by keeping carbon and nitrogen balanced in soil, otherwise microbes would decompose existing organic carbon of the soil (Fontaine et al. 2004; Murphy et al. 2015; Poeplau et al. 2017). The SOC was found increased under inorganic T2 also, which might be due to the fact that the application of urea 
assimilated carbon by improving leaf, shoot and root biomasses of rice plants (Liu et al. 2017; Ge et al. 2016; Zhu et al. 2018).

The highest available nitrogen was found under T4, which lowered the uptake of nutrients by the plants, thus lowered the rice yield in comparison to that under T2, T5 and T6. On the other hand, the total nitrogen replenished through T2, T5 and T6 was enough to balance the nutrients absorbed by the rice plants.

There was reduction in electrical conductance under T3-T6 in comparison to that under T2, which was in the lines of the findings by Claassen and Carey (2007), Walia et al. (2010) and Al-Bataina et al. (2016) from experiments with organic material-blended inorganic fertilizers. The reduction in electrical conductance under organic materialblended inorganic fertilizers slow down the release of dissolved nutrients than that under pure inorganic fertilizer, which helps plants to get nutrients progressively over their growing period. Performing the statistical Pearson correlation test with a significance level of $0.1 \%$, a strong positive correlation was found between SM and VWC with the correlation coefficient of 0.982 , and between manganese and copper with the correlation coefficient of 0.900 . The reason of it is that an increase in $\mathrm{pH}$ increases SM and VWC along with decreasing both redox potential (Eh) and electric conductance (EC), which in turn increase the availability of potassium, manganese, copper and zinc. A significant positive correlation with the correlation coefficient of 0.518 was found between TN and TC also, which indicates balanced fertilization in soil retaining enough moisture for decomposition of organic materials to SOC. On the other hand, available phosphorus and manganese showed a strong negative correlation with the correlation coefficient of -0.901 . The CAT also showed negative relations with SOC (having correlation coefficient of - 0.291) and VWC (having correlation coefficient of -0.237 ), which was due to the fact that an increase in VWC shifts microflora from aerobic to anaerobic ones and ultimately decreases the CAT (Brzezinska et al. 2005). The results obtained from PCA are summarized in Table 4 and also visualized in Fig. 1, where only those components having eigenvalues more than 1 are shown as they address $82.82 \%$ of the total variance. The first component of PCA (Component 1 in Fig. 1) showed strong correlations with $\mathrm{pH}, \mathrm{Eh}, \mathrm{EC}, \mathrm{SM}, \mathrm{VWC}, \mathrm{P}, \mathrm{K}, \mathrm{Cu}$, $\mathrm{Mn}$ and $\mathrm{Zn}$, where decrease in SM and VWC means a drop in the availability of $\mathrm{P}$ (phosphorus). Similarly, hydrogen ions $(\mathrm{pH})$ and flow of electrons (Eh and EC), linked to dissolved materials, determine the availability of micronutrients $(\mathrm{Cu}, \mathrm{Mn}$ and $\mathrm{Zn})$. The second component of PCA (Component 2 in Fig. 1) correlated $\mathrm{AN}$ and Fe, where the high correlation value with AN indicates the application of fertilizer. Finally, the third component of PCA (Component 3 in Fig. 1) showed positive correlation with TN and TC,
Table 4 Soil properties obtained through the principal component analysis (PCA) with the Varimax rotation method by satisfying the Kasier-Meyer-Olkin and Bartlett's tests

\begin{tabular}{|c|c|c|c|c|}
\hline Component & 1 & 2 & 3 & 4 \\
\hline Eigenvalue & 7.434 & 3.391 & 1.998 & 1.25 \\
\hline$\%$ Variance & 43.731 & 19.946 & 11.751 & 7.39 \\
\hline Cumulative variance $\%$ & 43.73 & 63.67 & 75.43 & 82.82 \\
\hline \multicolumn{5}{|c|}{ Rotated component matrix } \\
\hline $\mathrm{pH}$ & -0.816 & 0.212 & -0.167 & 0.260 \\
\hline $\mathrm{Eh}$ & 0.844 & -0.148 & 0.334 & -0.011 \\
\hline Ec & 0.448 & -0.168 & 0.626 & 0.016 \\
\hline $\mathrm{BD}$ & 0.228 & -0.073 & 0.324 & -0.824 \\
\hline SM & -0.723 & 0.561 & -0.179 & -0.003 \\
\hline VWC & -0.704 & 0.564 & -0.122 & -0.165 \\
\hline CAT & 0.240 & 0.089 & 0.904 & 0.074 \\
\hline SOC & 0.325 & 0.700 & 0.395 & 0.098 \\
\hline $\mathrm{TN}$ & 0.038 & -0.017 & 0.241 & 0.746 \\
\hline $\mathrm{TC}$ & -0.217 & 0.320 & 0.643 & 0.540 \\
\hline $\mathrm{N}$ & -0.137 & 0.873 & 0.212 & 0.024 \\
\hline $\mathrm{P}$ & -0.855 & 0.230 & -0.225 & -0.068 \\
\hline $\mathrm{K}$ & 0.457 & 0.199 & 0.645 & -0.237 \\
\hline $\mathrm{Cu}$ & 0.917 & 0.142 & 0.141 & -0.150 \\
\hline $\mathrm{Fe}$ & -0.145 & 0.931 & -0.132 & 0.072 \\
\hline $\mathrm{Mn}$ & 0.888 & -0.042 & 0.400 & -0.094 \\
\hline $\mathrm{Zn}$ & 0.889 & 0.354 & -0.137 & -0.153 \\
\hline
\end{tabular}

$E h$ redox potential; $E C$ electrical conductance; $B D$ bulk density; $S M$ soil moisture; $V W C$ volumetric water content; $C A T$ soil catalase activity; SOC soil organic carbon; $T N$ total carbon; $T C$ total carbon; $N$ nitrogen; $P$ phosphorus; $K$ potassium; $\mathrm{Cu}$ copper; $\mathrm{Fe}$ iron; $\mathrm{Mn}$ manganese; $Z n$ zinc

which indicated the mineralization/immobilization ability of the soil affecting BD of soil on the fourth component of PCA.

\section{Crop yield}

The rice yields and yield-attributing parameters obtained in the field experiment are presented in Table 5, where it is observed that the lowest yield of $(32.71 \pm 3.09) \mathrm{Q} / \mathrm{ha}$ was found under $\mathrm{T} 1$ and the highest yield of $(53.33 \pm 2.09) \mathrm{Q} /$ ha under T6. The absorption of a higher level of nitrogen $(\mathrm{C}: \mathrm{N}=10.58)$ by plants under $\mathrm{T} 6$ increased grain yields, which on the other side reduced the total nitrogen contents in the soil under T6. There was no statistical meaningful contrast in yield under T3 (NPK + crop residue) and T4 (NPK $+5 \mathrm{t} / \mathrm{ha}$ FYM. On the other hand, the yield under T4 (NPK +5 t/ha FYM) was less than that under T5 $(\mathrm{NPK}+10 \mathrm{t} / \mathrm{ha} \mathrm{FYM})$, which was due to the fact that the increased FYM enhanced soil properties. However, the efficiency of T2 (inorganic fertilizer NPK) could be enhanced only under T5 (NPK + FYM) and T6 (NPK + compost). 


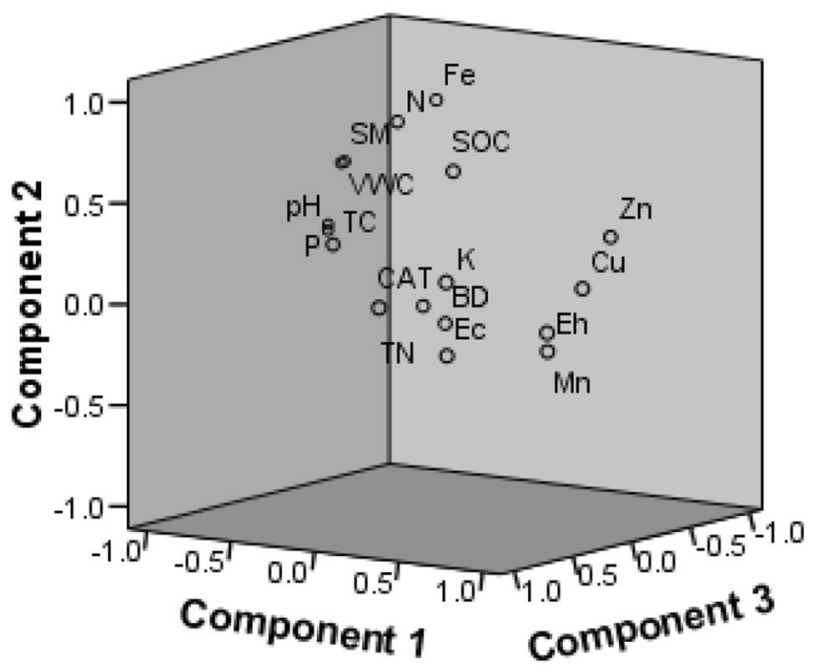

Fig. 1 Component plot of the principal component analysis (PCA) with the Varimax rotation method. Eh, redox potential; Ec, electrical conductance; BD, bulk density; SM, soil moisture; VWC, volumetric water content; CAT, soil catalase activity; SOC, soil organic carbon; $\mathrm{TN}$, total nitrogen; TC, total carbon; N, nitrogen; $\mathrm{P}$, phosphorus; $\mathrm{K}$, potassium; $\mathrm{Cu}$, copper; Fe, iron; $\mathrm{Mn}$, manganese; $\mathrm{Zn}$, zinc

Further, T5 was better than T6 in terms of many soil properties (refer Table 3). Still T5 cannot be considered as the finest fertilization practice in an acidic sandy soil, but T6 which showed better nitrogen-based factors (Table 6).

To optimize yield, it is necessary to identify the factors which affect the yielding and also the extents of their influences on yielding. However, no acceptable procedure has been established so far to analyze the yield-determining factors. The progression of plants and their net productivity in an ecosystem are usually evaluated by interacting different attributes. In the present study, the method of stepwise regression analysis proposed by Kosaki et al. (1989) was employed for evaluating the soil parameters which significantly contributed on rice yielding. Conducting the analysis with 17 soil parameters, only 2 of them (soil moisture and total carbon) were found affecting the rice yield significantly. About $70.4 \%$ variation in yield could be explained by soil moisture and additional $11.4 \%$ by incorporating total carbon with soil moisture. As soil moisture was found to enhance rice yield on a large degree, the dryness of soil in the summer season lessened the rice production in the experimental site.

\section{Conclusion}

Performing a 2-year field experiment on an acidic sandy loom soil under moist subtropical monsoon climate, rice yield could be improved through the application of NPK blended separately with organic crop residue, farm yard manure and compost made of bio-degradable household wastes. The highest yield was recorded under NPK blended with the compost, while the moisture and total carbon of the soil were found having significant positive impact on rice yielding. Various soil properties were also found improved from the application of organic materials with NPK. Further research may be carried out to investigate if such effects can be maintained in a sustainable way on large-scale application as well as for a longer period of time.

Open Access This article is distributed under the terms of the Creative Commons Attribution 4.0 International License (http://creativeco mmons.org/licenses/by/4.0/), which permits unrestricted use, distribution, and reproduction in any medium, provided you give appropriate credit to the original author(s) and the source, provide a link to the Creative Commons license, and indicate if changes were made.

Table 5 Effect of amendments on crop yield and its related attributes in a 2-year field experiment in the summer cropping seasons (Tukey's HSD test at significance level of 5\%)

\begin{tabular}{lllllllll}
\hline Treatment & $\begin{array}{l}\text { Productive till- } \\
\text { ers } / \mathrm{m}^{2}\end{array}$ & $\begin{array}{l}\text { Sterile tillers } \\
(\%)\end{array}$ & $\begin{array}{l}\text { Panicle length } \\
(\mathrm{cm})\end{array}$ & $\begin{array}{l}\text { Filled grain } \\
(\%)\end{array}$ & $\begin{array}{l}\text { Thousand } \\
\text { grain weight } \\
(\mathrm{g})\end{array}$ & $\begin{array}{l}\text { High-density } \\
\text { grains }(\%)\end{array}$ & $\begin{array}{l}\text { Harvest index } \\
(\%)\end{array}$ & $\begin{array}{l}\text { Yield (Q/ha) } \\
\text { ( })\end{array}$ \\
\hline T1 & $200.16 \pm 14.46$ & $19.13 \pm 0.52$ & $20.78 \pm 0.24$ & $54.30 \pm 4.39$ & $17.50 \pm 4.39$ & $48.12 \pm 6.03$ & $21.81 \pm 1.19$ & $32.71 \pm 3.09$ \\
T2 & $272.50 \pm 6.29$ & $15.13 \pm 1.35$ & $23.40 \pm 0.32$ & $72.79 \pm 4.01$ & $17.93 \pm 0.50$ & $60.73 \pm 2.76$ & $25.59 \pm 1.01$ & $46.07 \pm 4.31$ \\
T3 & $244.66 \pm 4.21$ & $10.26 \pm 1.33$ & $24.91 \pm 0.38$ & $79.35 \pm 2.12$ & $17.24 \pm 0.61$ & $60.86 \pm 2.76$ & $25.67 \pm 0.88$ & $43.40 \pm 4.06$ \\
T4 & $244.66 \pm 6.86$ & $14.25 \pm 1.32$ & $23.57 \pm 0.44$ & $80.04 \pm 2.76$ & $17.97 \pm 1.29$ & $70.53 \pm 2.40$ & $27.86 \pm 1.16$ & $43.63 \pm 4.14$ \\
T5 & $246.66 \pm 5.72$ & $13.57 \pm 2.16$ & $23.65 \pm 0.73$ & $78.28 \pm 2.51$ & $19.19 \pm 0.53 *$ & $71.26 \pm 3.25$ & $27.01 \pm 0.93$ & $47.46 \pm 2.51$ \\
T6 & $251.00 \pm 2.95$ & $11.74 \pm 0.71$ & $23.85 \pm 0.77$ & $82.63 \pm 2.75$ & $21.02 \pm 0.47$ & $73.66 \pm 2.07$ & $26.60 \pm 1.27$ & $53.33 \pm 2.09$ \\
\hline
\end{tabular}

Values (mean \pm standard error) with $*$ in the same column are significantly different. T1, No amendment, T2, NPK; T3, NPK + crop residue $(5 \mathrm{t} /$ ha); T4, NPK + farm yard manure (5 t/ha); T5, NPK + farm yard manure (10 t/ha); T6, NPK + compost $(2.5 \mathrm{t} / \mathrm{ha})$ 
Table 6 Evaluation of amendments in the perspective of $\mathrm{N}$ partial factor productivity $\left(\mathrm{PFP}_{\mathrm{N}}\right), \mathrm{N}$ agronomic efficiency $\left(\mathrm{AE}_{\mathrm{N}}\right)$, increased yield over $\mathrm{T} 2$ and yield contribution of $\mathrm{N}\left(\mathrm{YC}_{\mathrm{N}}\right)$, using mean data obtained from a 2-year field experiment in the summer cropping seasons

\begin{tabular}{lllll}
\hline Treatment & $\mathrm{PFP}_{\mathrm{N}}(\mathrm{kg} / \mathrm{kg})$ & $\mathrm{AE}_{\mathrm{N}}(\mathrm{kg} / \mathrm{kg})$ & $\begin{array}{l}\text { Increased } \\
\text { yield }(\%) \text { over } \\
\mathrm{T} 2\end{array}$ & $\mathrm{YC}_{\mathrm{N}}(\%)$ \\
\hline $\mathrm{T} 1$ & - & - & -40.84 & - \\
$\mathrm{T} 2$ & 52.27 & 14.77 & - & 28.26 \\
$\mathrm{~T} 3$ & 35.24 & 8.19 & -6.15 & 23.25 \\
$\mathrm{~T} 4$ & 41.70 & 10.42 & -5.59 & 25.00 \\
$\mathrm{~T} 5$ & 38.21 & 11.38 & 2.92 & 29.78 \\
$\mathrm{~T} 6$ & 56.34 & 21.18 & 13.61 & 37.73 \\
\hline
\end{tabular}

T1, No amendment; T2, NPK; T3, NPK + crop residue (5 t/ha); T4, $\mathrm{NPK}+$ farm yard manure $(5 \mathrm{t} / \mathrm{ha}) ; \mathrm{T} 5, \mathrm{NPK}+$ farm yard manure $(10 \mathrm{t} /$ ha); T6, NPK + compost $(2.5 \mathrm{t} / \mathrm{ha})$

\section{References}

Al-Bataina BB, Young TM, Ranieri E (2016) Effects of compost age on the release of nutrients I. Soil Water Conser Res 4(3):230-236. https://doi.org/10.1016/j.iswcr.2016.07.003

Anonymous (2015) Package of practices for Rabi crops of Assam, published jointly by Assam Agricultural University Jorhat and Department of Agriculture, Assam. https://diragri.assam.gov.in/ portlet-innerpage/package-of-practices. Accessed 02 Feb 2018

Baruah A, Baruah KK (2015) Organic manures and crop residues as fertilizer substitutes: impact on nitrous oxide emission, plant growth and grain yield in pre-monsoon rice cropping system. J Environ Prot 6:755-770. https://doi.org/10.4236/jep.2015.67069

Baruah A, Baruah KK, Gorh D, Gupta PK (2016) Effect of organic residues with varied carbon-nitrogen ratios on grain yield, soil health, and nitrous oxide emission from a rice agroecosystem. Commun Soil Sci Plant Anal 47:1417-1429. https://doi.org/10.1080/00103 624.2016.1178764

Bharali A, Baruah KK, Bhattacharyy P, Gorh D (2017) Integrated nutrient management in wheat grown in a northeast India soil: impacts on soil organic carbon fractions in relation to grain yield. Soil Till Res 168:81-91. https://doi.org/10.1016/j.still .2016.12.001

Brzezinska M, Włodarczyk T, Stepniewski W, Przywara G (2005) Soil aeration status and catalase activity. Acta Agrophys 5(3):555-565

Cassman KG, Peng S, Olk DC, Ladha JK, Reichardt W, Dobermann A, Singh U (1998) Opportunities for increased nitrogen-use efficiency from improved resource management in irrigated rice systems. Field Crop Res 56(1):7-39. https://doi.org/10.1016/S0378 $-4290(97) 00140-8$

Claassen VP, Carey JL (2007) Comparison of slow release nitrogen yield from organic soil amendments and chemical fertilizers and implication for regeneration of disturbed sites. Land Degrad Dev 8:119-132. https://doi.org/10.1002/ldr.770

Fontaine S, Bardoux G, Abbadie L, Mariotti A (2004) Carbon input to soil may decrease soil carbon content. Land Degrad Dev 7:314320. https://doi.org/10.1111/j.1461-0248.2004.00579.x

Franzluebbers AJ, Stuedemann JA (2009) Soil-profile organic carbon and total nitrogen during 12 years of pasture management in the Southern Piedmont USA. Argic Ecosyst Environ 29(1-3):28-36. https://doi.org/10.1016/j.agee.2008.06.013

Ge T, Li B, Zhu Z, Hu Y, Yuan H, Dorodnikov M, Jones DL, Wu J, Kuzyakov Y (2016) Rice rhizodeposition and its utilization by microbial groups depends on $\mathrm{N}$ fertilization. Biol Fertil Soils 53:37-48. https://doi.org/10.1007/s00374-016-1155-z

Gudadhe N, Dhonde MB, Hirwe NA (2015) Effect of integrated nutrient management on soil properties under cotton-chickpea cropping sequence in vertisols of Deccan plateau of India. Indian J Agric Res 49(3):207-214. https://doi.org/10.5958/0976058x.2015.00032.3

Guo S, Xu X, Gao L, Xie K, Ling N, Shen Q, Hu S, Guo S (2017) The rice production practices of high yield and high nitrogen use efficiency in Jiangsu, China. Sci Rep. https://doi.org/10.1038/s4159 8-017-02338-3

Kirkby CA, Richardson AE, Wade LJ, Batten GD, Blanchard C, Kirkegaard JA (2013) Carbon-nutrient stoichiometry to increase soil carbon sequestration. Soil Biol Biochem 60:77-86. https:// doi.org/10.1016/j.soilbio.2013.01.011

Kosaki T, Wasno K, Juo ASR (1989) Multivariate statistical analysis of yield determining factors. Soil Sci Plant Nutr 35(4):597-607. https://doi.org/10.1080/00380768.1989.10434795

Kowalijiow E, Mazzarino MJ (2007) Soil restoration in semiarid Patagonia: chemical and biological response to different compost quality. Soil Biol Biochem 39(7):1580-1588. https://doi. org/10.1016/j.soilbio.2007.01.008

Laos F, Satti P, Walter I, Mazzarino MJ, Moyano S (2000) Nutrient availability of composted and noncomposted residues in a Patagonian Xeric Mollisol. Biol Fertil Soils 31(6):462-469. https://doi. org/10.1007/s003740000192

Leip A, Weiss F, Lesschen J, Westhoek H (2014) The nitrogen footprint of food products in the European Union. J Agric Sci 152:20-33. https://doi.org/10.1017/S0021859613000786

Liu L, Hu C, Olesen JE, Ju Z, Yang P, Zhang Y (2013) Warming and nitrogen fertilization effects on winter wheat yields in northern China varied between 4 years. Field Crop Res 151:56-64. https:// doi.org/10.1016/j.fcr.2013.07.006

Liu Z, Rong Q, Zhou W, Liang G (2017) Effects of inorganic and organic amendment on soil chemical properties, enzyme activities, microbial community and soil quality in yellow clayey soil. PLoS ONE 12(3):e0172767. https://doi.org/10.1371/journ al.pone. 0172767

Murphy CJ, Baggs EM, Morley N, Wall DP, Paterson E (2015) Rhizosphere priming can promote mobilisation of N-rich compounds from soil organic matter. Soil Biol Biochem 81:236-243. https:// doi.org/10.1016/j.soilbio.2014.11.027

Page AL, Miller RH, Keeney DR (1982) Methods of soil analysis Part 2. Soil Sci Soc Am, Madison

Poeplau C, Reiter L, Berti A, Katterer T (2017) Qualitative and quantitative response of soil organic carbon to 40 years of crop residue incorporation under contrasting nitrogen fertilisation regimes. Soil Res 55:1-9. https://doi.org/10.1071/SR15377

Santhy P, Velusamy MS, Murryappan V, Selvi D (1999) Effect of inorganic fertilizers and fertilizer manure combination on soil physico-chemical properties and dynamics of microbial biomass in an inceptisol. J Indian Soc Soil Sci 37(3):379-382

Tian G, Gao L, Kong Y, Hu X, Xie K, Zhang R, Ling N, Sheng Q, Guo $S$ (2017) Improving rice population productivity by reducing nitrogen rate and increasing plant density. PLoS ONE 12(8):e0182310. https://doi.org/10.1371/journal.pone.0182310

Walia MK, Walia SS, Dhaliwal SS (2010) Long term effect of integrated nutrient management of properties of Typic Ustochrept after 23 cycles of an irrigated rice-wheat system. J Sustain Agric 33:723-733. https://doi.org/10.1080/10440046.2010.507519

Walkly A, Black IA (1934) An examination of the Degtjareff method for determining soil organic matter and a proposed modification of the chromic acid titration method. Soil Sci 37:29-38. https:// doi.org/10.1097/00010694-193401000-00003

Watanabe T, Luu HM, Inubushi K (2018) Effect of continuous application of rice straw compost and chemical fertilization on soil 
carbon and available silicon under a double rice cropping system in the Mekong delta, Vietnam. JPN Agric Res Q 51(3):233-239. https://doi.org/10.6090/jarq.51.233

Yung-Yu S (2005) Effect of application of different types of organic composts on rice growth under laboratory conditions. Soil Sci Plant Nutr 51(3):443-449. https://doi. org/10.1111/j.1747-0765.2005.tb00051.x

Zemanek P (2011) Evaluation of compost influence on soil water retention. Acta Univ Agric et Silvic Mendel Brun 3:227-232. https:// doi.org/10.11118/actaun201159030227

Zhang W, Zhang M, An S, Lin K, Li H, Cui C, Fu R, Zhu J (2012) The combined effect of decabromodiphenyl ether (BDE209) and copper $(\mathrm{Cu})$ on soil enzyme activities and microbial community structure. Environ Toxicol Phar 34:358-369. https:// doi.org/10.1016/j.etap.2012.05.009

Zhu Z, Ge T, Liu S, Hu Y, Yec R, Xia M, Tong C, Kuzyakov Y, Wu J (2018) Rice rhizodeposits affect organic matter priming in paddy soil: the role of $\mathrm{N}$ fertilization and plant growth for enzyme activities, $\mathrm{CO}_{2}$ and $\mathrm{CH}_{4}$ emissions. Soil Biol Biochem 116:369-377. https://doi.org/10.1016/j.soilbio.2017.11.001

Publisher's Note Springer Nature remains neutral with regard to jurisdictional claims in published maps and institutional affiliations. 